\title{
An Examination of Two Dimensions of Physician Perceived Value on Physician Satisfaction in the Yemeni Pharmaceutical Industry
}

\author{
Mohsen Ali Murshid ${ }^{1}$, Mohd Suberi Bin A. B. Halim² \& Abdullah Bin Osman ${ }^{2}$ \\ ${ }^{1}$ Faculty of Administrative Sciences, Thamar University, Yemen, School of Business Innovation and \\ Technopreneurship, University Malaysia Perlis, Malaysia \\ ${ }^{2}$ School of Business Innovation and Technopreneurship, University Malaysia Perlis, Malaysia \\ Correspondence: Abdullah Bin Osman, School of Business Innovation and Technopreneurship, University \\ Malaysia Perlis, Malaysia. E-mail: abos2137@yahoo.com
}

Received: April 2, 2014 Accepted: June 12, 2014 Online Published: July 24, 2014

doi:10.5539/ass.v10n16p14 URL: http://dx.doi.org/10.5539/ass.v10n16p14

\begin{abstract}
This paper explores the relationship between dimensions of perceived value by the physician and his level of satisfaction in the pharmaceutical industry in Yemen. The two dimensions of customer perceived value, namely, perceived quality (PQ) and perceived sacrifices (PS) are considered critical antecedents to physician satisfaction. Marketing researchers generally study two dimensions of perceived value, especially in the service sector: PQ and perceived sacrifice. However, the literature lacks studies on the two dimensions together, customer perceived value (CPV) (Li \& Green, 2011), and influence on customer satisfaction (CS). In this quantitative research, a survey of 170 physicians in Yemen was analyzed using the software SPSS version 19 adopting statistical techniques. The research results indicated the three hypothesized significant positive relationships between perceived value dimensions and physician satisfaction. However, PQ explained more of the variance in physician satisfaction than the perceived sacrifice. The empirical study and the results provided an evidence for managers that the critical influence of the dimension perceived values by the physician on his level of satisfaction in the pharmaceutical industry is important.
\end{abstract}

Keywords: pharmaceutical industry, perceived value, physician satisfaction, Yemen

\section{Introduction}

In the last few years, the pharmaceutical industry has witnessed profound changes in global progress. Intensive competition to gain market share has created new threats for drug manufacturers. In addition, the pharmaceuticals market has witnessed rapid and complex changes. However, the pharmaceutical industry is still one of the most inventive and profitable industries of the so-called 'high-tech' industry, holding one of the largest potentials in the world (Kesic, 2009). In addition, current increasing pressure for new product development, change in the competitive environment, and rate of technological change placed the pharmaceutical companies under pressure to maintain satisfaction and loyalty from the customers (George et al., 2006). The challenge for pharmaceutical companies is to become customer-centric companies, as product centricity is evidently no longer sufficient for success (Hazboun, 2006). The need for pharmaceutical companies to better interact with their customers is becoming more essential because the design of the marketing mix and its elements depend on the prescribers to the demand side, which are physicians (Vasiljev et al., 2010). Companies should develop and maintain a close relationship with customers to understand their needs and behavior (Sweidan et al., 2012). Therefore, pharmaceutical companies should pay more attention to the satisfaction of the customers (physicians) (Sweidan et al., 2012).

The reports of the Ministry of Health showed that the Yemeni market is becoming more open to foreign pharmaceutical companies that have strong brands and are focused on building a relationship with physicians (Al-Hamdi et al., 2012). In addition, the prevalent belief in Yemen promotes the appreciation and admiration of everything that is foreign and a negative view toward everything local, including drugs (Al-Tahami, 2010).This situation creates an imposing challenge because innovations and development alone do not guarantee the success of local pharmaceutical companies. To remain competitive in the Yemeni pharmaceutical industry, every drug company should understand the perceptions of the customers in using drugs to increase further their market share. In addition, companies need to understand the factors that might influence the satisfaction of the customers 
toward locally manufactured drugs. Therefore, satisfying customers is a very important issue for Yemeni pharmaceutical companies. Exploring customer perceived value and its underlying dimensions leads to a better understanding of the factors that make locally manufactured drugs more satisfying and competitive. Studies regarding perceived value and customer satisfaction (CS) issues in the pharmaceutical industry are very limited. This research attempts to explore the relationships of perceived value dimensions, namely, perceived quality (PQ) and perceived sacrifice, which will affect physician satisfaction toward locally manufactured drugs. The results of this research have academic and managerial implications. The result can provide valuable reference information for local pharmaceutical companies to enhance their drug quality and improve the satisfaction of their customers, especially physicians. For academics, the finding can be applied to medicinal marketing and further extension of this topic or related topics.

\section{Literature Review}

\subsection{Perceived Value of Physicians}

Interest on customer perceived value (CPV) has been increasing among marketing academics and researchers (Lapierre, 2000; Eggert \& Ulaga, 2002; Walter et al., 2001; Spiteri et al., 2004; Alireza, 2011; Faryabi et al., 2012). CPV is a common and essential issue in the marketing field, and is an important element in relationship marketing (MSI, 2001; Oh, 2003; Hague et al., 2012). Marketing practitioners and managers focus on CPV as a key strategic element to explain CS (Woodruff, 1997; Lee et al., 2007; Wang et al., 2006). To achieve long-term relationship, CPV is necessary to achieve CS. In the rapidly developing business environment, perceived value, which is strategically important for attraction and retention of customers, is a significant factor to the success of companies (Wang et al., 2004; Alireza et al., 2011) and is an important source of competitive advantage for the company (Spiteri \& Dion 2004; Cengiz et al., 2007). In other words, achieving a high perceived value for a physician is one of the key indicators of competitive advantage for pharmaceutical companies. Perceived value is a powerful measure of CS (Uddin et al., 2012). For example, if physicians receive positive value, they are satisfied; however, if they obtain negative value, they are dissatisfied with the drug product (Haque et al., 2013). In industrial marketing, consumer value perceptions have elicited little attention from researchers of industrial goods (Tsiotsou, 2005). Despite the importance of CPV in industrial markets, literature review surprisingly shows that only very limited research has been conducted to investigate CPV, e.g., Spiteri and Dion (2004), in the veterinary pharmaceutical industry. In this context, researchers and companies have little knowledge on how to define, measure, and deliver customer value (Anderson et al., 1998; Tzokas et al., 1999). Furthermore, perceived value has not been sufficiently and completely measured in empirical studies ( $\mathrm{Li}$ et al., 2011). More importantly, customer value varies for different relationship contexts, different environmental situations, and different countries (Menon et al., 2005). Thus, customer value needs to be investigated in a different business area (pharmaceutical industry), a different customer characteristic (physician), and a different competitive environment (Yemen). Thus, focusing on the pharmaceutical industry enables the attainment of in-depth understanding of this critical issue, with an emphasis on the value potential of the drug product. This study focuses on CPV in the pharmaceutical industry context, and thus, the customer refers to the customer of the physician that uses a drug product. The current research is part of the effort to discover customer (physician) value perceptions for drug products and to understand the role of CPV on satisfaction in the pharmaceutical industry.

\subsection{Perceived Value Dimensions of Physicians}

The traditional view of CPV in any industry, including the pharmaceutical industry, is that it is a construct containing two dimensions, one of benefits received (Sprang et al., 1993; Zeithaml, 1988 ; Monroe ,1990) and another of sacrifices made (cost/price, effort, and time) by the customers (Dodd's et al., 1991 ; Cronin et al., 2000; Cengiz et al., 2007; Ishaq, 2012).

$\mathrm{CPV}$ is a 'function of the overall quality and price of the firm's products and services compared to the competition' (Mokhtar et al., 2005). Zeithaml (1988) defined perceived value as "the consumers' overall assessment of the utility of a product based on perceptions of what is received and what is given" (Parasuraman \& Grewal, 2000; Cronin et al., 2000). According to Dodds et al. (1991) perceived value is conceptualized as a trade-off between the perceived qualities and perceived psychological desire, as well as monetary sacrifice. Similarly, Zeithaml (1988) and Monroe (1990) argued that CPV involves customers' per purchase evaluation of the rate of perceived benefits and perceived sacrifices. The benefits are outcomes of the product or service that lead to the higher level of values perceived by customers. It can be measured by the attribute quality, PQ (Yoo et al., 2000), and benefits of the product or service (Sprang et al., 1993).The sacrifices refer to the preferred maximum loss, as this assumes that customers generally want to minimize sacrifices. Perceived sacrifices may 
be thought of by many customers as the maximum sacrifices (cost, time, and effort) (Cronin et al., 2000; Cengiz et al., 2007).

Nevertheless, despite the multidimensional vision of CPV among researchers, these do not take into account the dimensions of perceived value, $\mathrm{PQ}$, and perceived sacrifices together in one study in measuring the perceived value as recommended ( $\mathrm{Li}$ et al., 2011). Thus, this study focuses on these dimensions as measures for the perceived value in the context of the pharmaceutical industry. This approach allows the elimination of some of the problems of the measure of perceived value, particularly its excessive concentration on economic utility (Dodds et al., 1991, Zeithaml, 1988; Monroe, 1990) and sacrifices (e.g., Cronin et al. 2000; Cengiz et al., 2007; Ishaq, 2012). Thus, in this context, perceived value is an evaluation of the benefits (PQ), sacrifice for the drug, such as price of drug, time spent, and perceived risk (side effect of drug), as perceived by the physician (Uddin et al., 2012; Haque et al., 2013).

Another important aspect of perceived value is that it echoes the perceived sacrifices in the pharmaceutical industry in buying and consuming drugs. As a result, this study claims that these dimensions should be included together in the measure and determination of the perceived value in the pharmaceutical industry. In particular, the constructs of perceived quality and CPV are closely linked to CS, and are sometimes even used synonymously in the literature (Walker, Johnson, \& Leonard, 2006; Rust \& Chung, 2006; Gilbert \& Veloutsou, 2006).

\subsubsection{Perceived Quality}

PQ has been a subject of considerable interest for both practitioners and researchers, mainly in the field of service marketing (Cronin \& Taylor, 1992; Parasuraman, Zeithaml, \& Berry, 1996; Cronin et al., 2000; Yoo et al., 2000). The perceived quality of a product is an important issue in the development and implementation of marketing strategies aimed at building the brand image of a company and increasing market share (Tsiotsou, 2005). PQ is directly related to the reputation of the manufacturer of a product (Davis et al., 2003). However, studies that integrate the role of PQ with CS receive less attention. Moreover, the relationships between these constructs in goods are well studied, unlike services, which have not been studied extensively in marketing (Tsiotsou, 2005). More research is necessary in studying the role of perceived quality in goods and related constructs, e.g., satisfaction (Tsiotsou, 2005). The PQ-CS relationship: In CS research, quality is regarded as the antecedent of CS (Cronin et al., 2000).

Moreover, PQ is defined as the judgment of the consumer about the overall excellence or superiority of a product (Zeithaml, 1988). PQ is different from the actual or objective quality of the product. It also includes more abstract levels of evaluation rather than a specific attribute of the product. In addition, it is a global assessment that in some cases resembles attitude. PQ is a judgment usually evoked by a consumer (Zeithaml, 1988). In this context, PQ is defined as the judgment of the physician about the overall excellence or superiority of the drug. This definition indicates that PQ is similar to the general attitude of the customer toward the product (Zeithaml, 1988). Several researchers have established a causal relationship between PQ and CS (Zeithaml, Berry, \& Parasuraman, 1988). Bolton et al. (1991) confirmed that PQ is negatively related to CS. Meanwhile. A study by Anderson and Sullivan (1993) found that CS is a function of PQ, and this quality has a greater effect on satisfaction and repurchase intention. In turn, Tsiotsou (2005) confirmed that PQ is an antecedent of CS. The author of the study recommends the importance of studying the PQ of goods, which could help marketing academics and practitioners more thoroughly study and manage PQ and related constructs (e.g., satisfaction). Thus, in the pharmaceutical context, the higher the quality of a drug product as perceived by the physician, the higher the satisfaction of the physician.

\subsubsection{Perceived Sacrifice}

According to Dodds et al. (1991) and Monroe (1990), the perceived sacrifice includes monetary (price) and nonmonetary (time, self-experiences, alternative products, or/and alternative brands) sacrifices. Zeithaml (1988) defines perceived sacrifice as encompassing all that has been sacrificed by the customer in return of receiving a product or service and all costs borne by the customer through the purchase. Perceived sacrifices comprise the monetary, referring to the perceived price that consumers have to pay, and the non-monetary, referring to the effort ,time, and perceived risk, which are all side effects that could be borne by the customer (Cronin et al.,2000). Nonmonetary costs, such as negotiation cost, transaction cost, search cost, and time incurred during the purchase, should also be included (Zeithaml, 1988; Keeney, 1999; Cronin et al., 2000; Chen et al., 2008). However, sacrifice means more than the money paid for certain goods.

Moreover, an empirical research by Cengiz et al. (2007) examined the relationship between perceived value (construct sacrifice) and CS. The results indicated that perceived value has positive effects on CS. By contrast, 
Sweeny et al. (1999) showed that perceived risk, as measured by the elements of performance and financial risk, has a more powerful, direct effect on CPV than price or PQ. Whereas Cronin et al. (2000) regarded risks as a component of sacrifice; this study extends the perceived sacrifice scale by including the aspects of risk of the drug product. This stance is taken because risks or side effects of the drug product are potential negative effects of the consumption of drugs.

\subsection{Satisfaction of Physicians}

CS has received much attention, and is one of the most popular research topics in marketing (Swenson, 1997; Yoon, 2010; Faryabi et al., 2012; Uddin et al., 2012; Haque et al., 2013). CS is an issue that cannot be overlooked in marketing strategies (Yang and Peterson, 2004) because it has critical influence on the long-term relationships between companies and customers (Patterson et al., 1997). Customer satisfaction is the necessary foundation for the company to retain existing customers, and is a key element in any customer retention strategy (Guo, Xiao, \& Tang, 2009; Oliver, 1999; Cronin \& Taylor, 1992). In the era of globalization, almost every drug company faces fierce competition. Customer (physician) satisfaction can be the one important tool to achieve competitive advantage (Raza et al., 2012).Nevertheless, the importance of the CS toward drug products within the pharmaceutical industry is still a relatively new topic in marketing.

Furthermore, several researchers emphasize that customer satisfaction can also be defined as an evaluative response to the perceived value outcome of a particular consumption experience (Cadotte et al., 1987; Hins, 1987; Boltton, 1998). Fornell (1992) defined CS as "the customer's overall evaluation of the consumption experience to date". In this context, CS refers to physician satisfaction, which is a component of overall CS that could be described as the overall evaluation of the physician of local drugs based on experience of the consumption of a drug over time (Fornell, 1992; Anderson et al., 1994).Thus, in the general field of pharmaceutical industry, satisfaction is an overall evaluation of all the aspects of a drug product. The primary customers of pharmaceutical companies are physicians who primarily interact with sales representatives (Sweidan et al., 2012; Kalaskar et al., 2012). In fact, physicians are powerful, having controlling access to the final consumers. Sweidan et al. (2012) believed that CS is an important factor for loyalty to pharmaceutical companies. Therefore, better understanding of the needs and behaviour of physicians brings about better relationship development.

\subsection{Relationship between Perceived Value and Satisfaction of Physicians}

The concepts of value and satisfaction are closely causally related to each other: value evaluation leads to feelings of satisfaction or dissatisfaction. Moreover, the evaluation criteria are basically the same, except that the assessment of CS mostly focuses on attribute-level evaluation, whereas CPV includes higher-order and more abstract levels of evaluation (Woodruff, 1997). Perceived value is the consequence of an overall assessment of PQ and perceived sacrifices, whereas satisfaction is an overall evaluation of the product value received by the customer (Woodruff, 1997). The literature review shows that the concept of CPV and CS differ from two ways: $\mathrm{CPV}$ is a more specific concept that is based on the product and its features, so CPV is a subjective concept, as the value of a product or service is the result of the subjective judgment of the customer (Zeithaml, 1988; Woodruff \& Gardial, 1996) of the perceived benefits relative to the sacrifice for the product (Lee et al., 2007), whereas CS can result from any dimension (e.g., expectations and loyalty) (Oliver et al., 1994). In addition, Eggert and Ulaga (2002) indicated that CPV and CS can be conceptualized and measured as two distinct, yet complementary, constructs. The distinction between the two is important for managers and practitioners alike, because their objective should be to satisfy consumers with their product or to deliver the maximum level of perceived value of product. Furthermore, most researchers who have investigated the relationship between CPV and CS assume that they are two different constructs, as CPV is seen as an antecedent of CS. Several empirical studies support this assumption (Cronin, Brady, \& Hult, 2000; Spiteri \& Dion, 2004: Cengiz et al., 2007; Lee et al., 2007; Uddin \& Akhter, 2012). In turn, CS is the result of CPV (Fornell et al., 1996; Faryabi et al., 2012; Ardabili et al., 2012).

The literature review shows that CPV may directly lead to the formation of overall satisfaction (Woodruff, 1997; Wang et al., 2006; Lee et al., 2007).Woodruff (1997) identified that measurement of CS without the achievement of CPV cannot truly meet the requirement of the customer. Therefore, CPV is the determinant of CS in the pharmaceutical industry (Heskett et al., 1997; Kotler et al., 2006; Moliner et al., 2007; Faryabi et al., 2012).

In the research of the relationship between CPV and CS, empirical studies have discovered that CPV positively influences CS in most industries (Cronin et al., 2000; Eggert \& Ulaga, 2002; Yang et al., 2004). Chen et al. (2008) focused on TV travel products, and found that CPV has a positive correlation with CS. A similar conclusion was proposed in studies of the banking industry (Faryabi et al., 2012) and Ardabili et al. (2012), who focused on 
electricity distribution companies. Heskett et al. (1997) focused on the tourism industry, and their result showed that the dimensions of perceived value (emotional value, functional value, and social value) have a direct or indirect influence on the satisfaction of the tourist. Similarly, Chen and Chen (2010) focused on the tourism context, and found that perceived experience quality of the tourist significantly and positively influences both the perceived value and satisfaction. Raza et al. (2012) focused on the hotel industry, and found that perceived value is significant and has a positive relationship with satisfaction. Lin et al. (2006) and Tung (2004) focused on the telecommunication sector, and found a positive relationship between CPV and CS. In the aspect of the pharmaceutical industry, studies regarding CPV and CS issues are very limited and scanty. An exception is Shaker (2012), who focused on the pharmaceutical industry and found that customers (Patients) stated that the perceived value of the drugs is their first priority without any consideration for the manufacturing place. In addition, Spiteri et al. (2004) focused on the veterinary pharmaceuticals industry, and found that perceived value is positively related to the overall satisfaction of physician. As a result, perceived value can be concluded as an important predictor of CS.

However, the work that integrates the role of CPV (perceived quality) with CS has received less attention in the industrial field. The relationships between these constructs in goods, rather than in services, have not been extensively studied in marketing (Tsiotsou, 2005). More importantly, the question of the relationship between perceived value and satisfaction has not been specified, e.g., Spreng (1993), and remains uncertain (Chen et al., 2008). Furthermore, the studies do not focus more on the dimensions of perceived value than the perceived value itself. Therefore, a better understanding of the relationship between the dimensions of CPV and CS may help academics develop a model of consumer decision making for drugs. It may also provide practitioners with indications on where best to devote marketing attention and scarce pharmaceutical corporate resources. Thus, based on the statement by previous researchers, this study aims to determine whether the overall CPV (perceived quality and perceived sacrifice) of a drug product would have a positive effect toward physician satisfaction.

\section{Conceptualization}

Based on the literature review, the conceptual model has been constructed. This model of satisfaction in the pharmaceutical industry comprises constructs and uniquely combines them in specifying that the physician satisfaction is a function of perceived value, perceived quality, and perceived sacrifice for the locally manufactured drug. Li et al. (2011) and Murshid, Halim \& Osman, (2014) suggested the inclusion of PQ and PS to measure PV and improve the understanding on PV measure issues. Thus, this research also aims to validate the effects of physician PV on the physician satisfaction relationship.Fig.1 shows the proposed conceptual model of the research.

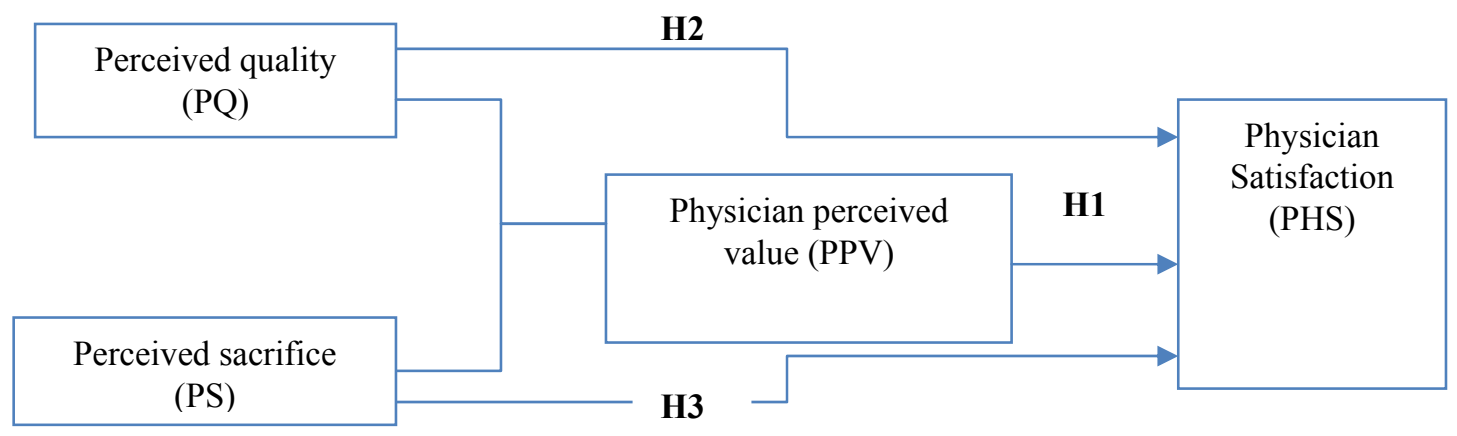

Figure 1. Conceptual research model

\section{Hypotheses}

The main purpose of this paper is to explore the relationships between the perceived value of the physicians and its dimensions, as well as customer satisfaction in the pharmaceutical industry. Based on the literature, directional relationships among overall perceived value, the dimensions of perceived value, and physician satisfaction are hypothesized. The following hypotheses are formulated as follows

H1: A significant relationship exists between the overall perceived value of the physicians (perceived quality and perceived sacrifice) and physician satisfaction in the pharmaceutical industry.

H2: A significant relationship exists between perceived quality and physician satisfaction in the pharmaceutical 
industry.

H3: A significant relationship exists between perceived sacrifice and physician satisfaction in the pharmaceutical industry.

\section{Methodology}

Random sampling was used to assess opinions of physicians regarding perceived value and his level of satisfaction with locally manufactured drugs. The respondents of this study were physicians working in different clinics and hospitals. The reason for choosing the sampling technique was that the data of the physicians were not publicly available, and this study was conducted to improve understanding about the antecedents of CS in the pharmaceutical industry. Moreover, they have more experience in local drug products. five hundred questionnaires via a self-administered were distributed to the respondents, among which 192 were returned at the end of September 2013 but only 170 questionnaires were usable (response rate $=34 \%$ ) for statistical regression analysis. The survey was conducted over a three-month period. In addition, physician satisfaction was measured using the five-item scale of Bloemer et al. (2002). PV is the total measure of the PQ and PS of physician's .Perceived quality was measured using four items drawn from Yoo et al. (2000). Perceived sacrifice was measured using five measures taken from Cronin et al. (2000). One item called 'side effects of drugs" to the scale of perceived sacrifice (cost, time, effort, and side effect) was developed and added to adapt with the context of the research (pharmaceutical). Moreover, each of the named constructs was measured using a five-point rating scale $(1$ = strongly disagree; 2 = disagree; 3 = neutral; 4 = agree; and $5=$ strongly agree $)$.

\section{Analysis and Results}

\subsection{Reliability and Descriptive Statistics}

SPSS software version 19 was used to analyze data. Descriptive analysis was conducted to determine the demographic backgrounds of the physicians. Nunnally (1978) suggested that the minimum Cronbach's alpha of 0.7 sufficed for the early stage of research. The Cronbach's alpha coefficient for all constructs was 0.7 , which is in line with the recommended threshold (Hair et al., 1998, 2006, 2010). The constructs were therefore deemed to possess adequate reliability. The descriptive statistics and reliability analysis are shown in Table 1.

Table 1. Descriptive statistics and reliability analysis results

\begin{tabular}{lllll}
\hline Variables & No. of item(s) & Mean & SD & Alpha (a) \\
\hline Overall Perceived value & 9 & 2.93 & 0.672 & 0.875 \\
Perceived quality & 4 & 2.82 & 0.818 & 0.902 \\
Perceived sacrifice & 5 & 3.02 & 0.716 & 0.796 \\
Physician satisfaction & 5 & 3.06 & 0.881 & 0.935 \\
\hline
\end{tabular}

The Cronbach's alpha values were calculated (see Table 1) to assess the internal consistency the scales. The alpha values for perceived value dimensions are as follows: PQ $(\alpha=0.902)$, and PS $(\alpha=0.796)$. The overall perceived value score is high $(\alpha=0.875)$. The alpha value for physician satisfaction is very high $(\alpha=0.935)$. The mean scores for all dimensions are as follows: overall PV (2.93) PQ (2.82), and PS (3.02). Physician satisfaction shows the mean score of 3.06. The findings from descriptive statistics showed acceptable mean and standard deviation.

\subsection{Exploratory Factor Analysis (EFA)}

EFA with principal component method was used to identify the underlying dimensionality of the perceived value with varimax rotation in pharmaceuticals. PV comprises two dimensions, namely, perceived quality (4 items) and perceived sacrifice (5 items), which reflect the perceived value of the physicians toward locally manufactured drugs. Table 2 shows the results of the varimax-rotated analysis of the perceived value of the physicians and its related variables. 
Table 2. Factor analysis for perceived value and physician satisfaction

\begin{tabular}{lllll}
\hline Construct & Item & Loading & Eigen value & Average Variance Explained (AVE) \\
\hline Perceived value & PQ2 & 0.857 & & \\
KMO =0.879; sig $=0.000$ & PQ3 & 0.851 & & \\
Perceived quality & PQ4 & 0.850 & 4.61 & 36.75 \\
& PQ1 & 0.825 & & \\
& PS4 & 0.825 & & \\
Perceived sacrifice & PS3 & 0.732 & & \\
& PS5 & 0.654 & 1.53 & 29.65 \\
& PS1 & 0.654 & & \\
& PS2 & 0.614 & & \\
Physician satisfaction & PHS3 & 0.903 & & \\
KMO $=0.883 ;$ sig $=0.000$ & PHS1 & 0.903 & & \\
& PHS2 & 0.892 & 3.96 & \\
& PHS5 & 0.880 & & \\
& PHS4 & 0.872 & & \\
\hline
\end{tabular}

As presented in Table 2, the factor loading of each measure is from 0.825 to 0.857 for perceived quality, and from 0.614 to 0.825 for perceived sacrifice, which is more than the suggested practical significance of 0.50 (Hair et al., 2010). In addition, the results show that Bartlett's test of sphericity is significant $(p=0.000)$. The KMO value is 0.879 , which exceeded the recommended minimum value of 0.50 (Hair et al., 2010). In addition, principal components analysis reveals the presence of two components with eigen values exceeding 1, accounting for $36.75 \%$ and $29.65 \%$, respectively. The KMO value for physician satisfaction is 0.879 , which exceeds minimum value of $0.50(\mathrm{sig}=0.000)$. Factor loading for items is ranged from 0.872 to 0.903 . Thus, the internal validity of the measurement model is adequate .The findings of these tests show the suitability of data for factor analysis (FA).

\subsection{Regression Analysis}

The purpose of regression analysis is to determine the significant effect or influence of the independent variable on the dependent variable (Ndubisi, 2006). In this paper, the perceived value of the physicians is considered as the independent variable or predictor variable and the customer or physician satisfaction is considered as the dependent variable. Table 3 shows the summary of the results of hypotheses testing. It was used to determine the effect of three independent variables, namely, perceived value, perceived quality, and perceived sacrifice on the physician satisfaction on pharmaceutical industry.

Table 3. Result of hypotheses testing

\begin{tabular}{lllllll}
\hline Research hypotheses & $\mathrm{R}^{2}$ & $\beta$ & Std Error & $t$-value & sig. & Result \\
\hline H1 PV $\rightarrow$ Physician satisfaction & 0.410 & 0.643 & 0.077 & 10.816 & .000 & Supported \\
H2 PQ $\rightarrow$ Physician satisfaction & 0.388 & 0.626 & 0.064 & 10.33 & .000 & Supported \\
H3 PS $\rightarrow$ Physician satisfaction & 0.260 & 0.514 & 0.080 & 7.71 & .000 & Supported \\
Significant at $\mathrm{p}<0.05$. & & & & & & \\
\hline
\end{tabular}

The findings of the simple regression analysis summarized in Table 3 show that the overall perceived value of the physicians significantly contributes $(\boldsymbol{\beta}=0.643, \boldsymbol{t}=10.81, \mathrm{p}<0.05)$ to physician satisfaction and predicts $41.0 \%$ of the variation found. Thus, $\mathrm{H} 1$ is supported, indicating that the perceived value has a direct relationship with physician satisfaction. This result indicates that if the perceived value of the physician of the drug is higher, satisfaction will be higher. Therefore, pharmaceutical companies should concentrate more on creating and improving perceived value from their customers and other stakeholders. The results also show that the two dimensions of perceived value all had significantly positive effects on physician satisfaction. In other words, the perceived quality has significant $(\boldsymbol{\beta}=0.626, \boldsymbol{t}=10.33, \mathrm{p}<0.05)$ influence on physician satisfaction, and 
perceived sacrifices $(\boldsymbol{\beta}=0.514, \boldsymbol{t}=7.71, \mathrm{p}<0.05)$ are given high importance by the physicians in the pharmaceutical industry of Yemen. Thus, $\mathrm{H} 2$ and $\mathrm{H} 3$ are supported.

\section{Discussion and Conclusions}

The main objective of this study is to investigate the effect of perceived value dimensions, perceived quality, and perceived sacrifice on the overall satisfaction of the physician. This investigation confirmed previous findings on the important role of perceived value on consumer behavior in pharmaceuticals, leading to the identification of the effects that different dimensions of perceived value have on physician overall satisfaction. Perceived quality and perceived sacrifice had significant, positive relationships with physician satisfaction.

Several researchers have indicated that a need for a better measure for perceived value ( $\mathrm{Li}$ et al., 2011; Woodruff, 1997; Murshid et al., 2014) as a key strategic element in explaining customer satisfaction exists (Woodruff, 1997; Wang et al., 2006; Faryabi et al., 2012). In line with this thought, the findings of this research point to the need to develop and use the dimensions of perceived quality and perceived sacrifice in the CPV construct measure. This result confirms those of Li et al. (2011), and Murshid et al. (2014) suggesting that CPV research is critically dependent on the perceived quality and perceived sacrifice of the operational measures. According to $\mathrm{Li}$ et al. (2011), this finding is important because the construct measurements are as important as the examination of substantive relationships. Thus, the relationship of the CPV construct with satisfaction may be affected by whether the construct dimensions are operationalized or not. The current study presents a methodology for developing a measure of CPV construct in the pharmaceutical industry.

Moreover, the results show that the perceived quality of the drug has a significant and positive influence on the satisfaction of the physician. This result is consistent with a previous study (Yoo et al., 2000). Cengiz et al. (2007) conducted a research on accounting offices in Turkey, and found that perceived value and perceived quality have a positive effect on customer satisfaction. Ardabili et al. (2012) found that a direct positive relationship exists between perceived service quality aspects (performance and relation) and CS through the perceived value. The present study indicates that the perceived sacrifice for drugs has a significant effect on the satisfaction of physicians, which is consistent with a previous study (Cronin et al., 2000). Cronin et al. (2000) examined the relationship among perceived value (construct sacrifice), service quality, CS, and consumer behavioral intention in the service industry. The findings indicate that perceived value (sacrifices) has a positive influence on CS. Similarly, Faryabi et al. (2012) found positive relationship between CPV and CS in the Iran banking industry. The results of this study also provide empirical support for the conceptualization of perceived value and satisfaction by Chen et al. (2008). Similarly, Uddin et al. (2012) stated that perceived value has a positive influence on CS in the telecom industry.

\section{The Theoretical and Practical Implications}

\subsection{Theoretical Implications}

For the theoretical perspective, the study findings demonstrate that constructs other than perceived quality and perceived sacrifice need to be incorporated for CS to extend the current theories of CPV (Woodroof, 1997; Li et al., 2011; Murshid et al., 2014) In turn, the present research extends the existing customer (physician) satisfaction model by incorporating three antecedents in the proposed model, presenting a more comprehensive representation of physician satisfaction in the pharmaceutical industry. Thus, theory building in pharmaceuticals could benefit from examining the issues from multiple perspectives and providing additional insights. In addition, this study contributes a more profound understanding of the multifaceted nature of the CPV concept, specifically in relation to the tradeoff between benefit (perceived quality) and perceived sacrifices. The study also contributes to the theory development of pharmacological marketing by exploring the perceived value of physicians in the pharmaceutical industry and its effect on their satisfaction, a context that has not been sufficiently addressed in existing studies. Therefore, this paper contributes to industrial and relationship marketing theories by introducing a multidimensional perceived value model for assessing the direct influence it has on satisfaction.

\subsection{Practical Implications}

The findings of this empirical research show that in the context of the pharmaceutical industry, perceived value and its dimensions are antecedents of physician satisfaction. More specifically, perceived value, from a multidimensional perspective, is identified as the key variable in the formation of satisfaction. This result shows, or at least, helps the marketing managers understand better the key role that physician satisfaction assigns to perceived value. For the maintenance of long-term relationships with customers and the achievement of their satisfaction, paying attention to perceived value and its different dimensions is fundamental. Thus, marketing managers in local pharmaceutical companies are recommended to develop operations and marketing strategies 
that focus on $\mathrm{CPV}$ dimensions, which can enhance CS, especially of physicians.

In addition, the results indicate that the dimensions of perceived value, perceived quality, and perceived sacrifices are important influencing factors on physician satisfaction. Pharmaceutical firms should understand the importance of the quality and value of the drug to customers, especially physicians. The findings also show that perceived value dimensions, perceived quality, and perceived sacrifice have positive direct influences on physician satisfaction. Thus, the positive effect of perceived quality, low perceived sacrifice, and consequently, increased perceived value, makes physicians satisfied. Therefore, marketing managers should ensure drug quality.

Moreover, this research provides an opportunity for marketing managers in local pharmaceutical companies to analyze physician perceptions of the value of local drugs at a higher level of abstraction. It also allows marketing managers to assess the contribution of a theoretically important dimension of the perceived value and their relationship with satisfaction. In turn, a need for intervention in a specific dimension (e.g., perceived quality or perceived sacrifices) to improve the satisfaction of physicians was identified. The findings also indicate that delivering superior physician value is one of the most important factors for the success of any pharmaceutical firm at present and in the future because it has a significant effect on physician satisfaction. The present research is a new study conducted in the Yemeni pharmaceutical market, and its results provide assistance for local pharmaceutical companies to better satisfy their customers.

\section{Limitation and Future Research}

This research has some limitations. First, this research is limited to one sector (pharmaceutical industry). Given the exploratory nature of the research, this approach may be justified. Thus, replicating the research in several industries, e.g., healthcare and hospital would be valuable to confirm the perceived value dimensions identified in this research or to refine further the technical dimensions that may be applicable to the perceived value. Second, in the aspect of sampling respondents, this research selected only the main customer of pharmaceutical companies (physicians). Future studies can extend the scope to other consumer groups, such as pharmacists and patients in the same industry. Third, future research may apply the model of this survey in an experimental setting using scenarios to manipulate key constructs, e.g., perceived quality and perceived sacrifice, which are antecedents of customer perceived value or customer satisfaction, because CPV is a mediator between perceived quality, sacrifice, and customer satisfaction. Finally, other factors that will influence customer satisfaction toward drugs, such as quality and perceived risks should be included.

\section{References}

Al-Hamdi, A., Hassali, M., \& Izham, M. (2012). Impact of pharmaceutical promotion on healthcare professional's practices and behavior views from general practitioners, medicine dispensers and medical representatives in Yemen. Journal of Medical Marketing: Device, Diagnostic and Pharmaceutical Marketing, 10(0), 1-7.

Alireza, S. M., \& Ghaedi, M. (2011). A survey on the relationships between perceived value and customer advocacy behavior. International Conference on Innovation, Management and Service. IPEDR 14, (2011) IACSIT Press, Singapore.

Al-Tahami, K. (2010). A comparative Quality Study of Selected Locally Manufactured and Imported Medicines in Yemeni Market. Yemeni Journal for Medical Sciences, 4, 8-13.

Anderson, E. W., \& Sullivan, M. (1993). The antecedents and consequences of customer satisfaction for firms. Mark. Sci., 12(2), 125-143. http://dx.doi.org/10.1287/mksc.12.2.125

Anderson, E. W., Fornell, C., \& Lehmann, D. R. (1994). Customer Satisfaction, Market Share, and Profitability: Findings from Sweden. Journal of Marketing, 58, 53-66. http://dx.doi.org/10.2307/1252310

Anderson, J. C., \& Narus, J. A. (1998). Business Marketing: Understand What Customers Value. Harvard Business Review, 76(6), 53-65.

Anderson, R. E., \& Srinivasan, S. S. (2003). E-satisfaction and e-loyalty: A contingency framework. Psychology and Marketing, 20(2), 123-138. http://dx.doi.org/10.1002/mar.10063

Ardabili, F. S., Daryani, S. M., Molaie, M., Rasooli, E., \& Kheirava, M. (2012). Importance of mutual relations on customer satisfaction in industries with no/low direct contact with customers. African Journal of Business Management, 6(29), 8637-8643.

Bloemer, J., \& Odekerken-Schröder, G. (2002). Store satisfaction and store loyalty explained by customer-and store-related factors. Journal of Consumer Satisfaction, Dissatisfaction and Complaining Behavior, 15, 
68-80.

Bolton, R. N. (1998). A dynamic model of the duration of the customer's relationship with a continuous service Provider: The role of satisfaction. Marketing Science, 17(1), 45-65. http://dx.doi.org/10.1287/mksc.17.1.45

Bolton, R. N., \& Drew, J. H. (1991). A multistage model of customer's assessments of service quality and value. Journal of Consumer Research, 17, 375-384. http://dx.doi.org/10.1086/208564

Boulding, W., Kalrs, A., Staelin, R., \& Zeithaml, V. A. (1993). A Dynamic Process Model of Service Quality: From Expectations to Behavioral Intentions. Journal of Marketing Research, 30(1), 7-27. http://dx.doi.org/10.2307/3172510

Cadotte, E. R., Robert, B. W., \& Jenkins, R. L. (1987). Expectations and Norms in Models of Consumer Satisfaction. Journal of Marketing Research, 24, 305-314. http://dx.doi.org/10.2307/3151641

Cengiz, E., \& Yayla, H. E. (2007). The effect of marketing mix on positive word of mouth communication: Evidence from accounting offices in Turkey. Innovative Marketing, 3(4), 73-86.

Chen, C. F., \& Chen, F. S. (2010). Experience quality, perceived value, satisfaction and behavioral intentions for heritage tourists. Tourism Management, 31, 29-35. http://dx.doi.org/10.1016/j.tourman.2009.02.008

Chen, C. F., \& Tsai, M. H. (n. d.). Perceived value, satisfaction, and loyalty of TV travel product shopping: Involvement as a moderator. Tourism Management, 29, 1166-1171.

Clottey, T., Collier, D., \& Stodnick, M. (2008). Drivers of customer loyalty in a retail store environment. J. Serv. Sci., 1(1), 35-48.

Cronin, J. J. Jr., \& Taylor, S. A. (1992). Measuring Service Quality: A Reexamination and Extension. Journal of Marketing, 56(3), 55-69. http://dx.doi.org/10.2307/1252296

Cronin, J. J., Brady, M. K., \& Hult, G. T. M. (2000). Assessing the effects of quality, value, and customer satisfaction on consumer behavioral intentions in service environments. Journal of Retailing, 76(2), 193-218. http://dx.doi.org/10.1016/S0022-4359(00)00028-2

Davis, A., \& Chase. (2003). Fundamentals of Operations Management (4th ed.). McGraw-Hill/Irwin, ISBN: 0-07-297541-5.

Dodds, W. B., Monroe, K. B., \& Grewal, D. (1991). Effects of price, brand, and store information on buyers' product evaluations. Journal of Marketing Research, 28(3), 307-319. http://dx.doi.org/10.2307/3172866

Eggert, A., \& Ulaga, W. (2002). Customer perceived value, A substitute for satisfaction in business markets. Journal of Business and Industrial Marketing, 17(2/3), 107-118. http://dx.doi.org/10.1108/08858620210 419754

Faryabi, M., Kaviani, F., \& Yasrebdoost, H. (2012). The relationship between Customer Perceived Value and Customers Satisfaction in Banking Industry in Iran. Australian Journal of Basic and Applied Sciences, 6(12), 76-85.

Fornell, C. (1992). A national satisfaction barometer: The Swedish experience. J. Mark., 56(1), 6-21. http://dx. doi.org/10.2307/1252129

Fornell, C., Michael, D., Johnson, E. W. A., Cha, J., \& Bryant, B. E. (1996). The American Customer Satisfaction Index: Nature, Purpose, and Findings. Journal of Marketing, 60(4), 7-18. http://dx.doi.org/10. $2307 / 1251898$

George, N., Lodorfos, K. L., \& Mulvana, J. T. (2006). Consumer Behaviour: Experience, Price, Trust and Subjective Norms in the OTC Pharmaceutical Market. Innovative Marketing, (2), 3.

Gilbert, G., \& Veloutsou, C. (2006). A cross-industry comparison of customer satisfaction. Journal of Service Marketing, 20(5), 298-308. http://dx.doi.org/10.1108/08876040610679918

Guo, L., Xiao, J. J., \& Tang, C. (2009). Understanding the psychological process underlying customer satisfaction and retention in a relational service. Journal of Busin, 62, 1152-1159. http://dx.doi.org/10. 1016/j.jbusres.2008.10.020

Hair, J. F. J. R., Black, W. C., Babin, B. J., \& Anderson, R. E. (2010). Multivariate Data Analysis (7th ed.). Upper Saddle River, NJ: Prentice Hall.

Hair, J. F. J., Black, W. C., Babin, B. J., Anderson, R. E., \& Tatham, R. L. (2006). Multivariate data analysis (6th ed.). Englewood Cliffs, NJ: Prentice-Hall. 
Hair, J. F., Anderson, R. E., Tatham, R. L., \& Black, W. C. (1998). Multivariate data analysis. New Jersey: Prentice-Hall.

Haque, A., \& Highe, A. K. (2013). Factors influencing of tourist loyalty: A study on tourist destinations in Malaysia. Proceedings of 3rd Asia-Pacific Business Research Conference, 25-26. Kuala Lumpur, Malaysia.

Hazboun, R. K. (2006, August). Strategic Application of CRM: The case of the Palestinian Pharmaceutical Industry. M.B.A. Dissertation Maastricht University, Netherland.

Heskett, J. L., Sasser, W. E., \& Schlesinger, L. A. (1997). The Service Profit Chain. New York, NY: The Free Press.

Hines, J. M., Hungerford, H. R., \& Tomera, A. N. (1987). Analysis and synthesis of research on responsible environmental behavior: A meta-analysis. Journal of Environmental Education, 18, 1-8. ISSN 1991-8178. http://dx.doi.org/10.1080/00958964.1987.9943482

Huddleston, P., Whipple, J., Mattick, R. N., \& Lee, S. J. (2009). Customer satisfaction in food retailing: Comparing specialty and conventional grocery stores. International Journal of Retail \& Distribution Management, 57(1), 63-80. http://dx.doi.org/10.1108/09590550910927162

Ishaq, M. (2012). Perceived Value, Service Quality, Corporate Image and customer Loyalty: Empirical Assessment From. Pakistan. Serbian Journal of Management, 7(1), 25-36. http://dx.doi.org/10.5937/sjm 1201025I

Kalaskar, P. B., \& Sager, P. N. (2012). Factors influencing prescription behavior of physicians: A study with reference to Marathwada Regio. Indian Streams Research Journal, 2(IV), 1-4.

Keeney, R. L. (1999). The value of internet commerce to the customer. Management Science, 45(4), 533-542. http://dx.doi.org/10.1287/mnsc.45.4.533

Kesic, D. (2009). Strategic analysis of the world pharmaceutical industry. Management, 14(1), 59-76.

Kotler, P., \& Armstrong, G. (2006). Principles of marketing (11th ed.). New York: Pearson International.

Lapierre, J. (2000). Customer-perceived Value in Industrial Context. Journal of Business \& Industrial Marketing, 15(2/3), 122-140. http://dx.doi.org/10.1108/08858620010316831

Lee, C. K., Yoon, Y. S., \& Lee, S. K. (2007). Investigating the Relationships among Perceived Value, Satisfaction and Recommendations: The Case of the Korean DMZ. Tourism Management, 28, 204-214. http://dx.doi. org/10.1016/j.tourman.2005.12.017

Li, M. L., \& Green, R. D. (2011). A mediating influence on customer loyalty: The role of perceived value. Journal of Management and Marketing Research, 7, 1-12.

Lin, H. H., \& Wang, Y. S. (2006). An examination of the determinants of customer loyalty in mobile commerce contexts. Information and Management, 43(3), 271-282. http://dx.doi.org/10.1016/j.im.2005.08.001

Marketing Science Institute (MSI). (2001). 2002-2004 Research Priorities. A Guide to MSI Research Programs and Procedures. Marketing Science Institute.

Menon, A., Homburg, C., \& Beutin, N. (2005). Understanding customer value in Business-to-Business relationships. Journal of Business to Business Marketing, 12(2), 1. http://dx.doi.org/10.1300/J033v12n 0201

Mokhtar, A. S., Abbas, K. A., Sapuan, S. M., \& Ahmad, M. M. H. (2005). Consumer's acceptability estimation of cold preserved Malaysian freshwater patin. Am. J. Applied Sci., 2, 985-988. http://dx.doi.org/10.3844/ajassp. 2005.985.988

Moliner, M. A., Sanchez, J., Rodriguez, R. M., \& Callarisa, L. (2007). Relationship quality with a travel agency: The influence of the post-purchase perceived value of a tourism package. Tourism and Hospitality Research, 7(3/4), 194-211. ISSN: 15469239. http://dx.doi.org/10.1057/palgrave.thr.6050052

Monroe, K. B. (1990). Pricing, Making Profitable Decisions (2nd ed.). McGraw-Hill, New York.

Murshid, M. A., Halim, M. S., \& Osman, A. (2014). Marketing Mix Strategy and Physicians' Satisfaction: A Mediation Effect of Perceived Value in the Pharmaceutical industry in Yemen. IOSR Journal of Humanities and Social Science (IOSR-JHSS), 19(5), 73-81. http://dx.doi.org/10.9790/0837-19517381

Ndubisi. (2006). Relationship dissolution model: Antecedents of relationship commitment and the likelihood of dissolving a relationship. International Journal of Service Industry Management, 9(2), 189-200. 
Nikolaos, S., \& Michael. (1999). Value transformation in relationship marketing. Australasian Marketing Journal, 7(1), 52-62. http://dx.doi.org/10.1016/S1441-3582(99)70202-8

Nunnally, J. O. (1 978). Psychometric theory. New York: McGraw-Hill.

Oh, H. (2003). Price fairness and its asymmetric effects on overall price, quality, and value judgments: The case of an upscale hotel. Tourism Management, 24, 241-249. http://dx.doi.org/10.1016/S0261-5177(02)00109-7

Oliver, R. (1994). A conceptual model of service quality and service satisfaction: Compatible goals, different concepts. Advances in Consumer Research, 21, 16-22.

Oliver, R. (1997). Satisfaction: A Behavioral Perspective on the Consumer. McGraw-Hill, Boston.

Oliver, R. L. (1993). Cognitive, Affective, and Attribute Bases of the Satisfaction Response. Journal of Consumer Research, 20(3), 418-430. http://dx.doi.org/10.1086/209358

Oliver, R. L. (1999). Whence consumer loyalty? Journal of Marketing, 63(Special issue), 33-44. http://dx.doi. org/10.2307/1252099

Palmatier, R. W., Dant, R. P., Grewal, D., \& Evans, K. R. (2006). Factors influencing the effectiveness of relationship marketing: A meta-analysis. Journal of Marketing, 70(3), 136-153. http://dx.doi.org/10.1509/ jmkg.70.4.136

Parasuraman, A., \& Grewal, D. (2000). The impact of technology on the quality-value-loyalty chain: A research agenda. J. Acad. Mark Sci., 28(1), 168-174. http://dx.doi.org/10.1177/0092070300281015

Parasuraman, A., Zeithaml, V., \& Berry, L. (1996). The behavioral consequences of service quality.

Raza, M., Siddiquei, A., Awan, H., \& Bukhari, K. (2012). Relationship between Service Quality, Perceived Value, Satisfaction and Revisit Intention in Hotel Industry. Interdisciplinary Journal of Contemporary Research in Business, 4(8), 788-805.

Reichheld, F. F., \& Sasser, W. E. (1990). Zero defections: Quality comes to services. Harv. Bus. Rev., 68(5), 105-111.

Rust, R. T., \& Chung, T. S. (2006). Marketing Models of Service and Relationships. Marketing Science, 25(6), 560-580. http://dx.doi.org/10.1287/mksc.1050.0139

Spiteria, J. M., \& Paul, A. D. (2004). Customer value, overall satisfaction, end-user loyalty, and market performance in detail intensive industries. Industrial Marketing Management, 33, 675-687. http://dx.doi. org/10.1016/j.indmarman.2004.03.005

Spreng, R. A., Dixon, A. L., \& Richard, W. O. (1993). The impact of perceived value on consumer satisfaction. Journal of Consumer Satisfaction, Dissatisfaction and Complaining Behavior, 6, 50-55.

Sweeny, J. C., Soutar, G. N., \& Johnson, L. W. (1999). The Role of Perceived Risk in the Quality-Value Relationship: A Study in a Retail Environment. Journal of Retailing, 75(1), 77-105. http://dx.doi.org/10. 1016/S0022-4359(99)80005-0

Sweidan, G., Al-Dmour, H., Zu'bi, M. F., \& Al-Dmour, R. (2012). The effect of relationship marketing on customer Loyalty in the Jordanian pharmaceutical industry. European Journal of Economics, Finance and Administrative Sciences, 53, 153-172.

Tsiotsou, R. (2005). Perceived quality levels and their relation to involvement, satisfaction and purchase intentions. Marketing Bulletin, 16, 1-10.

Tuan, N. M. (2012). Effects of Service Quality and Price Fairness on Student Satisfaction. International Journal of Business and Social Science, 3(19).

Tung, L. L. (2004). Service quality and perceived value's impact on satisfaction, intention and usage of short message service (SMS). Information Systems Frontiers, 6(4), 353-368. http://dx.doi.org/10.1023/B:ISFI. $0000046377.32617 .3 \mathrm{~d}$

Uddin, M. B., \& Akhter, B. (2012). Customer satisfaction in Mobile Phone services in Bangladesh. A survey Research Management \& Marketing, $X(1)$.

Vasiljev, S., \& Pantelic, D. (2010). Pharmaceutical Market(ing): Theory and Reality. 'Club of Economics in Miskolc' TMP, 6(2), 85-91.

Walter, A., Ritter, T., \& Hans-Georg, G. (2001). Value Creation in Buyer Seller Relationships. Theoretical Considerations and Empirical Results from a Supplier's. 
Wang, Y., Lo, H. P., \& Yang, Y. (2004). An integrated framework for service quality, customer value, satisfaction: Evidence from China's telecommunication industry.

Wong, A., \& Sohal, A. S. (2006). Understanding the quality of relationships in consumer services: A study in a retail environment. The international Journal of Quality \& Reliability Management, 23(2/3), 244-264. http://dx.doi.org/10.1108/02656710610648215

Woodruff, R. B. (1997). Customer value: The next source for competitive advantage. Academy of Marketing Science, 25(2), 139-153. http://dx.doi.org/10.1007/BF02894350

Woodruff, R. B., \& Gardia, S. (1996). Know Your Customer: New Approaches to Customer Value and Satisfaction. Blackwell Publishers Ltd.

Yang, Z. R. T. (2004). Peterson, Customer Perceived Value, Satisfaction, and Loyalty. The Role of Switching Costs, Psychology and Marketing, 21(10), 799-822. http://dx.doi.org/10.1002/mar.20030

Yoo, B., Donthu, N., \& Lee, S. (2000). An examination of selected marketing mix elements and brand equity. Journal of the Academy of Marketing Science, 28(2), 195-211. http://dx.doi.org/10.1177/0092070300 282002

Yoon, C. (2010). Antecedents of Customer Satisfaction with Online Banking in China: The effects of Experience. Computers in Human Behavior, 26, 1296-1304. http://dx.doi.org/10.1016/j.chb.2010.04.001

Zeithaml, V. (1988). Consumer perceptions of price, quality, and value: A means-end model and synthesis of evidence. Journal of Marketing, 52, 2. http://dx.doi.org/10.2307/1251446

\section{Copyrights}

Copyright for this article is retained by the author(s), with first publication rights granted to the journal.

This is an open-access article distributed under the terms and conditions of the Creative Commons Attribution license (http://creativecommons.org/licenses/by/3.0/). 